DOI: https://doi.org/10.32839/2304-5809/2021-4-92-68

УДК 379.851

Сирота М.Є., Дронова Т.С.

Дніпровський національний університет імені Олеся Гончара

\title{
ДІЯЛЬНІСТЬ ТУРИСТИЧНОГО ПІДПРИЄМСТВА ПП «КАЙФ»
}

\begin{abstract}
Анотація. У статті висвітлено особливості теоретичних та практичних засад фрормування і реалізації ефективної маркетингової стратегії підприемства з метою удосконалення товарної політики в умовах кризи. Проаналізовано діяльність підприемства на основі SNW-аналізу, що показав сильні сторони, які має ПП «Кайфр» для розвитку, та слабкі, за якими потрібно пильно слідкувати. Було здійснено аналіз мікросередовища туристичного підприемства, визначено оцінку конкурентоспроможності туристичних послуг підприемства. Також було визначено оцінку позицій туристичного підприемства ПП «КАЙФ» серед головних конкурентів та зроблено аналіз зовнішнього середовища підприемства за допомогою PEST-aналізу. На основі цього запропоновано низку заходів, які потрібно втілити для розвитку ПП «Кайдр» та підвищення конкурентоспроможності.
\end{abstract}

Ключові слова: конкурентоспроможність, ринок туристичних послуг, конкурентні переваги, туристичні послуги, турагенти, товарна стратегія.

Syrota Marharyta, Dronova Tatiana Oles' Honchar Dnipro National University

\section{ACTIVITY OF A TOURISM ENTERPRISE PE «KAIF»}

Summary. The article highlights the peculiarities of theoretical and practical principles of formation and implementation of an effective marketing strategy of the enterprise in order to improve product policy in a crisis. The activity of the enterprise is analysed on the basis of SNW-analysis, which showed the strengths that PE "Kaif" has for development, and weaknesses that need to be closely monitored. The analysis of the microenvironment of the tourist enterprise was carried out, the estimation of competitiveness of tourist services of the enterprise is defined. It was also determined the assessment of the position of the tourist enterprise PE "KAIF" among the main competitors and made an analysis of the external environment of the enterprise using PEST-analysis. Based on this, a number of measures are proposed that need to be implemented for the development of PE "Kaif" and increase competitiveness. According to the World Tourism Organization [4], the number of international tourist trips in the world before the COVID-19 pandemic was 1.5 billion in 2019. The growth rate of this indicator was $4 \%$ compared to 2018. This confirms that tourism is a leading and sustainable sector of the economy. The market of tourist services in Ukraine is also developing rapidly, and in the coming years this industry may become an important sector of business. That is why the priority of many tourism entities is to increase market share, which requires in-depth marketing research that will examine the needs and demands of consumers, determine their preferences for the tourism product, communication channels, prices and logistics services. Solving the problems of marketing product policy at any economic level requires a strategic approach, so any decisions in this area should be made not only taking into account current interests, but also with an understanding of how it will affect the ultimate goals of the enterprise. In market conditions, the company is forced to make independent decisions on the choice of strategy and tactics of the product policy. Thus, the company must have available and constantly improve the product strategy, which in turn will lead to a stable range of products, constant sales and stable profits. All this determines the relevance of the chosen topic.

Keywords: competitiveness, market of tourist services, competitive advantages, tourist services, travel agents, product policy.

$\Pi$ остановка проблеми. У ринковій економіці суб'єкти господарювання самостійно обирають методи проведення товарної політики. Вони визначають і виробляють саме ті товари, які потребують користувачі. Пропонують ринку нові та модифіковані товари, різну кількість та види товарів, що представляють собою товарний мікс підприемства.

За таким принципом працюе приватне підприемство «Кайфр». Воно постійно удосконалюе структуру товарного асортименту у відповідності iз потребами ринку. Працює над безперервним збутом продукції та стабільністю прибутку.

Аналіз досліджень і публікацій. Важливість проблеми зумовила защікавленість до їі дослідження багатьох вітчизняних та зарубіжних вчених таких, як: Котлер Ф., Ансофрd I., Ламбен Ж.-ЖЖ., Ілляшенко С.М., Каїра 3.С., Васютинська Ю.О., Багіев Г.Л., Малюк С.О., Могилова А.Ю., Головко А.В., Крикавський Є.В., Дронова Т.С. та низки інших.
Виділення невирішених раніше частин загального питання. 3 метою формування едективної товарної політики потребують подальшого вирішення такі питання: організація фонкціонування в межах існуючої номенклатури товарів, враховуючи їх життевий цикл, заміщення та елімінація товарів на ринку.

Мета статті. Проаналізувати мікро- та макросередовище підприемства та запропонувати стратегію подальшого розвитку.

Виклад основного матеріалу. Ефективне фонкціонування підприемства на ринку забезпечується розробкою та оптимізацією товарної номенклатури й асортименту товару, товарною стратегією.

Науковці не дійшли єдиної згоди щодо визначення типів товарних стратегій. Але в узагальненому вигляді товарні стратегії вони поділяються на: розробку продукту (інноваційна стратегія), стратегія модифікації (диференціація, варіація), стратегія елімінування $[1 ; 2 ; 6]$ (рис. 1 ). 


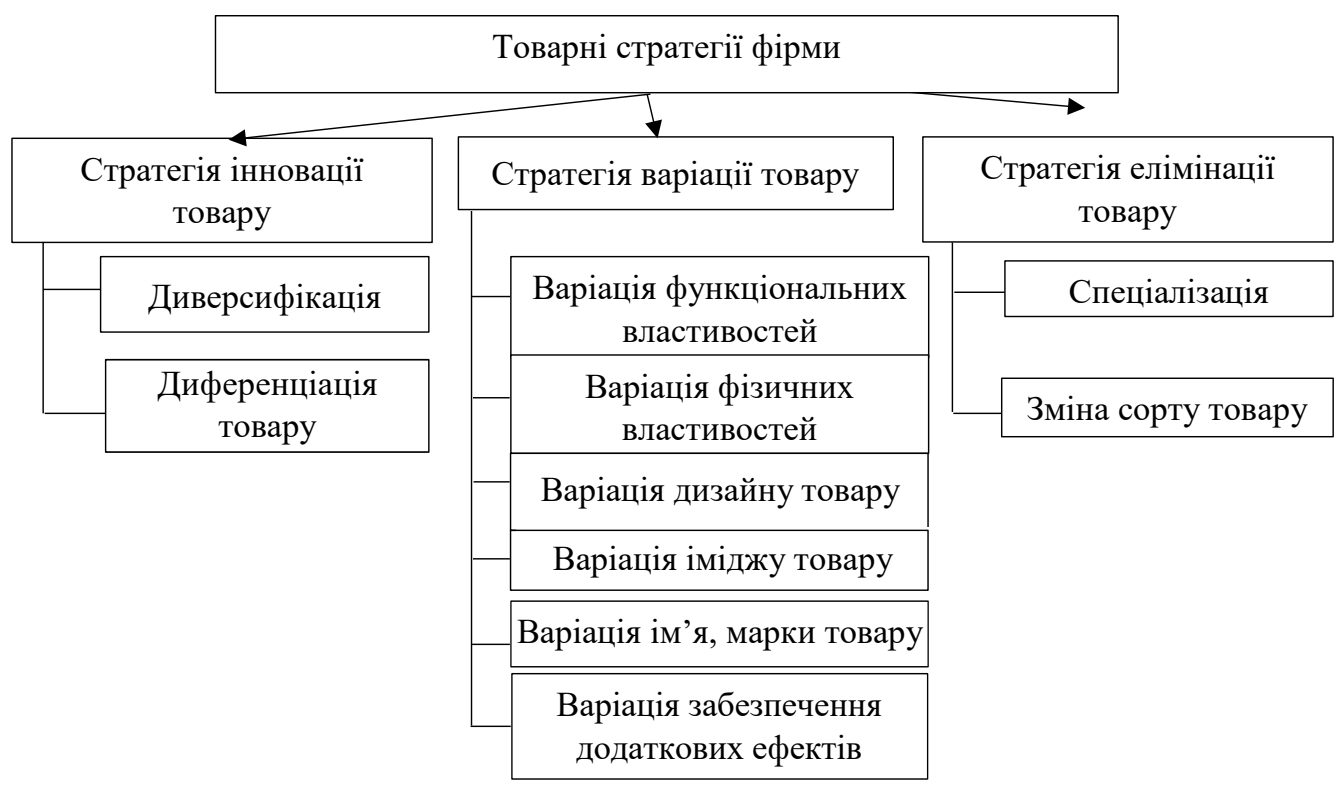

Джерело: [3, с. 260]

Рис. 1. Товарні стратегії фірми

Відсутність товарної стратегії негативно позначається на діяльності підприемства i, як наслідок, з'являеться нестійка структура асортименту, втрачаються конкурентні позищії та зменшуеться прибуток. Тому, з метою оптимізації ходу оновлення товарної лінійки та вчасного реагування підприемства на зміну фракторів зовнішнього та внутрішнього середовища, постає необхідність у вдалому виборі товарної стратегії.

Створення та контроль товарного асортименту відбувається за допомогою набору дій, методів та принципів діяльності підприемства. Ефективне фоункціонування товарної політики сприяе високій конкурентоздатності товарів, пошуку оптимальних товарних ніш, розробці та впровадженні сервісного обслуговування товару.

Розробка товарної політики відбуваеться із врахуванням ряду факторів: рівень попиту і потреби споживачів, технологічні можливості підприемства, наявність товарів-замінників тощо.

В залежності від галузі діяльності, підприемство самостійно обирає альтернативні та ефрективні товарні стратегії функціонування. Це забезпечуе суб'єкту господарювання стійкість асортиментної структури, безперервний збут продукції та стабільність прибутку. На вибір підприемством товарної стратегії впливають такі фрак- тори: фрінансовий стан, галузева приналежність, конкурентні переваги на ринку, імідж тощо.

В сучасних умовах розвитку туристичного ринку спостерігається низка кризових явищ, спричинена зовнішніми та внутрішніми фракторами: глобалізація, дезорганізація товарно-грошового обігу, соціальні та політичні чинники, пандемія (із 2020 року). Туристична галузь до 2020 року була однією із найперспективніших, динамічно розвивалась та приносила державі прибуток. З'являлись нові види туризму, галузь переходила на все вищі й вищі етапи розвитку.

Але тенденція наростання кризових явищ торкнулася і України. За даними Державної служби статистики України, кількість суб'єктів туристичної діяльності скоротилася за 2013-2019 рр. на $13,8 \%$, у тому числі туроператорів - на $24,6 \%$, турагентів - на 9,7\%. Середньооблікова кількість штатних працівників на туристичних підприємствах знизилася на $8,1 \%$ (табл. 1 ).

Туристична фірма ПП «Кайфр» - самостійна юридична особа, що здійснюе свою турагентську діяльність на підставі ліцензії. За формою організації діяльності - турагент. За формою власності - приватне підприемство. Головним сегментом споживачів послуг підприемства $є$ молодь та сімейні люди.

Динаміка кількості суб’ектів туристичної діяльності

Таблиця 1 та штатних працівників в Україні [5]

\begin{tabular}{|c|c|c|c|c|}
\hline \multirow{2}{*}{ Рік } & \multirow{2}{*}{\begin{tabular}{c} 
Кількість суб'ектів \\
туристичної \\
\cline { 3 - 4 }
\end{tabular}} & \multicolumn{2}{|c|}{ У томучислі } & $\begin{array}{c}\text { Середньооблікова } \\
\text { кількість штатних } \\
\text { працівників, осіб }\end{array}$ \\
\hline 2013 & 2586 & туроператори & турагенти & 11198 \\
\hline 2014 & 2198 & 831 & 1685 & 9834 \\
\hline 2015 & 1785 & 667 & 1473 & 8086 \\
\hline 2016 & 1838 & 500 & 1228 & 8545 \\
\hline 2017 & 1743 & 552 & 122 & 8190 \\
\hline 2018 & 1833 & 498 & 1172 & 8934 \\
\hline 2019 & 1867 & 529 & 1243 & 9120 \\
\hline
\end{tabular}


Досліджуване туристичне підприемство ПП «Кайфр» пропонуе найкращі курорти та готелі в 28 країнах світу - в Туреччині, Іспанії, Греції, Сгипті, Таїланді, Болгаріі, Тунісі, Марокко, Ізраїлі, ОАЕ, Андоррі, Австрії, Китаї, на Кубі, в Індії, на Маврикії, в Танзанії, Домініканській Республіці, Індонезії, на Мальдівах, у В'єтнамі, на Сейшелах, Шрі-Ланці, в Сінгапурі, Мексиці, Камбоджі, Йорданії та України. Також, туристичне підприемство постійно намагаеться відкривати нові напрямки. Турагент організовуе групові та індивідуальні тури, розвиває incentive-, congress-, спортивний та інші види туризму.

Основні туристичні напрямки компанії - Туреччина і Єгипет. В різний час тури в ці країни займали від 40 до 80 \% загального об'єму перевезень. ПП «Кайфр» починає активно розвивати напрямок «працевлаштування за кордоном», також плануеться розвиток окремої мережі у цьому напрямку.

Для аналізу внутрішнього середовища туристичного підприемства ПП «КАЙФ» проведемо $\mathrm{SNW}$-аналіз за яким оцінюеться стан внутрішнього середовища підприемства за низкою позицій. Кожна позиція отримуе одну із трьох оцінок:

- сильна (Strength);

- нейтральна (Neutral);

- слабка (Weakness).

SNW-аналіз туристичного підприемства ПП «КАЙФ» наведено в табл. 2.

Головне завдання SNW-аналізу - виявлення «активу» (S) i «пасиву» (W) підприемства. Завдання нової стратегії розвитку - використання акти- ву для нейтралізації і усунення пасиву. 3 цією метою нами проведено SNW-аналіз туристичного підприемства ПП «КАЙФ» (табл. 2). технології, що використовується. Кожна позиція була оцінена експертами підприємства за 10-ти бальною шкалою.

Отже, провівши SNW-аналіз туристичного підприемства ПП «КАЙФ», можна дійти висновку, що до сильних сторін підприемства відносяться: якість наданих послуг, цінова політика, психологічний клімат в колективі та умови праці. Також, було виявлено, що до слабких сторін відносяться: стратегія підприемства, організація маркетингу та обсяг реалізації послуг фірми.

3 метою визначення перспектив подальшого розвитку підприємства, проведено аналіз мікросередовища туристичного підприемства ПП «КАИФ» представлено у табл. 3. Ступінь впливу фракторів було оцінено експертами підприемства за 5-ти бальною шкалою.

Проаналізувавши дані, надані у таблиці 3, можна дійти до висновку, що найвпливовішими фракторами мікросередовища є високий ступінь прихильності покупців до послуг фрірми, надання посередниками вигідних для фрірми фрорм оплати та умов отримання послуг, низький рівень поінформованості покупців про товари (продукти) підприемства, ступінь задоволеності покупців сервісом підприємства, досить висока чутливість покупців до ціни.

Одним із критеріїв ощінки конкурентоспроможності туристичного підприемства ПП «КАЙФ» $е$ конкурентоспроможність наданих

SNW-аналіз туристичного підприемства ПП «КАЙФ»

Таблиця 2

\begin{tabular}{|c|c|c|c|c|}
\hline № 3/п & $\begin{array}{c}\text { Ключові параметри діяльності } \\
\text { туристичної фрірми } \\
\end{array}$ & $\mathbf{S}$ & $\mathbf{N}$ & W \\
\hline 1 & Навчання персоналу & & 5 & \\
\hline 2 & Умови праці & 9 & & \\
\hline 3 & Мотивація і стимулювання персоналу & 8 & & \\
\hline 4 & Плинність кадрів & & & 5 \\
\hline 5 & Кваліфікація персоналу & & 5 & \\
\hline 6 & Оцінка якості роботи персоналу & & 6 & \\
\hline 7 & Соціальний пакет & & 5 & \\
\hline 8 & Організація планування & & & 3 \\
\hline 9 & Рівень технічної оснащеності & & 5 & \\
\hline 10 & Інформаційне забезпечення & 8 & & \\
\hline 11 & Якість послуг, що надаються & 10 & & \\
\hline 12 & Організація маркетингу на підприемстві & & & 2 \\
\hline 13 & Обсяги реалізації & & & 2 \\
\hline 14 & Асортимент продукції, що випускається & & 6 & \\
\hline 15 & Чисельність персоналу & & & 3 \\
\hline 16 & Заробітна плата & 8 & & \\
\hline 17 & Імідж (ділова репутація) підприемства & & 7 & \\
\hline 18 & Психологічний клімат у колективі & 9 & & \\
\hline 19 & Фінансова стійкість підприемства & & 5 & \\
\hline 20 & Територіальне розташування & & 5 & \\
\hline 21 & Цінова політика & 9 & & \\
\hline 22 & Обсяги продажів & & & 3 \\
\hline 23 & Орієнтація на споживача & 8 & & \\
\hline 24 & Стратегія розвитку підприемства & & & 2 \\
\hline
\end{tabular}


Аналіз мікросередовища туристичного підприемства ПП «КАЙФ»

\begin{tabular}{|c|c|c|c|}
\hline Можливість & \begin{tabular}{|l|} 
Ступінь \\
впливу \\
\end{tabular} & Загроза & $\begin{array}{l}\text { Ступінь } \\
\text { впливу }\end{array}$ \\
\hline \multicolumn{4}{|c|}{ Споживачі } \\
\hline $\begin{array}{l}\begin{array}{l}\text { Виявлення тенденції зростання цільового } \\
\text { ринку }\end{array} \\
\end{array}$ & 3 & $\begin{array}{l}\text { Високий ступінь мінливості потреб, вимог і } \\
\text { смаків покупців }\end{array}$ & 2 \\
\hline Виявлення потенційного попиту & 4 & $\begin{array}{l}\text { Значна привабливість цільового сегменту } \\
\text { для конкурентів }\end{array}$ & 3 \\
\hline $\begin{array}{l}\text { Високий ступінь прихильності покупців до } \\
\text { послуг фрірми }\end{array}$ & 5 & $\begin{array}{l}\text { Слабка здатність підприемства до } \\
\text { едективного функціонування в } \\
\text { привабливому ринковому сегменті }\end{array}$ & 3 \\
\hline $\begin{array}{l}\text { Обмежена можливість покупців у виборі } \\
\text { інших продавців }\end{array}$ & 3 & $\begin{array}{l}\text { Низький ступінь задоволеності покупців } \\
\text { товарами (сервісом) підприемства }\end{array}$ & 4 \\
\hline $\begin{array}{l}\text { Висока чутливість покупщів до реклами, } \\
\text { різних дій щодо стимулювання збуту }\end{array}$ & 3 & $\begin{array}{l}\text { Низький рівень інформованості покупців } \\
\text { про товари підприємства }\end{array}$ & 4 \\
\hline $\begin{array}{l}\text { Сприятливе ставлення покупців до } \\
\text { інноваційних рішень підприемства в галузі } \\
\text { асортиментної політики }\end{array}$ & 2 & Висока чутливість покупщів до ціни & 4 \\
\hline \multicolumn{4}{|c|}{ Посередник } \\
\hline $\begin{array}{l}\text { Укладення довгострокових договорів } \\
\text { співпраці з посередниками }\end{array}$ & 4 & Відсутність пільг з боку посередників & 2 \\
\hline $\begin{array}{l}\text { Надання посередниками вигідних для } \\
\text { фірми форм оплати та умов надання послуг }\end{array}$ & 4 & $\begin{array}{l}\text { Скорочення кількості посередників, які } \\
\text { надають необхідні для підприемства } \\
\text { послуги }\end{array}$ & 4 \\
\hline $\begin{array}{l}\text { Розширення кількості посередників } \\
\text { підприемства }\end{array}$ & 3 & $\begin{array}{l}\text { Збільшення кількості посередників на } \\
\text { шляху від виробника до підприємства } \\
\text { Посилення тиску з боку посередників }\end{array}$ & 3 \\
\hline \multicolumn{4}{|c|}{ Конкуренти } \\
\hline $\begin{array}{l}\text { Нові конкуренти стимулюють розвиток } \\
\text { турфрірми }\end{array}$ & 4 & $\begin{array}{l}\text { Поява нових конкурентів, що веде } \\
\text { до зниження стійкості фрірми на } \\
\text { туристичному ринку м. Дніпро }\end{array}$ & 4 \\
\hline
\end{tabular}

Джерело: складено автором за даними підприєлства

туристичних послуг. Для більш якісного аналізу даний критерій проаналізовано детальніше методом, що базується на теорії ефрективної конкуренщії. Зміст даного підходу полягає в бальній оцінці можливостей підприємства щодо забезпечення конкурентоспроможності. Всі сфрормульовані в ході аналізу його можливості, спрямовані на досягнення конкурентних переваг, оцінюються експертами з позиції наявних ресурсів і фракторів. Оціночні критерії експерти підприемства визначили за шкалою - "задовільно", "добре", "відмінно" (табл. 4).

Аналіз зовнішнього середовища полягає в ощінюванні фракторів як непрямого впливу, так і прямого впливу на підприемство, і дає змогу визначити певні можливості і загрози. До зовнішніх фракторів, що прямо впливають на діяльність туристичного підприємства ПП «КАЙФ» має сенс віднести:

1. Постачальники. Постачальники є одним 3 провідних фракторів, які мають вплив на діяльність туристичного підприемства. Цінова політика постачальників-туроператорів прямо пропорційно впливає на цінову політику туристичного підприемства ПП «КАЙФ». Оскільки туристичний продукт є основним видом діяльності підприемства, слід приймати даний фрактор як один $з$ основних.

2. Інфрляційні процеси в країні. Цей фрактор має прямий вплив на цінову політику підприемства, оскільки підвищення рівня цін у країні взагалі призводить до підвищення цін на туристичний продукт, який являеться основним видом діяльності туристичного підприемства ПП «КАЙФ».
3. Законодавство країни. У даний час, українське законодавство знаходиться на тому етапі розвитку, що підприемства, які займаються туристичною діяльністю вимушені постійно адаптувати свою діяльність згідно до законодавчих актів. Слід зазначити, що законодавство України змінюеться доволі часто і залежачи від того чи може підприємство швидко адаптуватися до нових умов праці 3 залученням мінімальних ресурсів залежить чи має воно у результаті конкурентні переваги на ринку. Саме тому законодавство варто вважати впливовим фрактором у діяльності підприемства.

4. Суміжні ринки. Даний фрактор має опосередкований вплив на фрункціонування підприемства на ринку через те, що розвиток суміжних ринків впливає на ринок туристичних послуг, а він, в свою чергу, впливає на розвиток всіх ринків. Розвиток туризму в Україні безпосередньо залежить від таких секторів економіки, як транспорт, торгівля, зв'язок, будівництво, сільське господарство, виробництво товарів широкого вжитку і туристичного призначення. Туризм розглядають як одну 3 провідних галузей в cфpepi структурної перебудови економіки.

Для вивчення середовища непрямого впливу туристичного підприемства ПП «КАЙФ» проведено PEST-аналіз. Абревіатура PEST поєднуе в собі перші літери слів: "Policy», «Economy», «Socety», «Technology», що в перекладі - політика, економіка, соціум (суспільство), технологія.

У табл. 5 представлено PEST-аналіз макросередовища туристичного підприемства ПП «КАЙФ». 
Оцінка конкурентоспроможності туристичних послуг підприемства ПП «КАЙФ»

Таблиця 4

\begin{tabular}{|c|c|c|c|}
\hline \multirow{2}{*}{$\begin{array}{l}\text { Критерії } \\
\text { оцінки }\end{array}$} & \multicolumn{3}{|c|}{ Характеристика оціночних критерї̈в } \\
\hline & “задовільно" & "добре" & "відмінно" \\
\hline 1 & 2 & 3 & 4 \\
\hline 1. Ціна & Висока ціна & Середня ціна на ринку & $\begin{array}{l}\text { Створення оптимального рівня } \\
\text { цін з відповідними послугами } \\
\text { для споживачів з різним рівнем } \\
\text { доходу (гнучкі ціни), враховуючи } \\
\text { циклічність розвитку економіки }\end{array}$ \\
\hline 2. Якість & $\begin{array}{l}\text { Відповідае } \\
\text { вимогам трьох-, } \\
\text { чотирьох-зіркових } \\
\text { готелів, будинків } \\
\text { відпочинку та } \\
\text { курортів } \\
\end{array}$ & $\begin{array}{l}\text { Відповідає вимогам трьох-, } \\
\text { чотирьох-, п’яти- зіркових } \\
\text { готелів, будинків відпочинку } \\
\text { та курортів }\end{array}$ & $\begin{array}{l}\text { Відповідає вимогам трьох-, } \\
\text { чотирьох-, п’ятизіркових готелів, } \\
\text { будинків відпочинку та курортів }\end{array}$ \\
\hline 3. Асортимент & $\begin{array}{l}\text { Вузько-профільні } \\
\text { послуги }\end{array}$ & $\begin{array}{l}\text { Деякі відомі місця відпочинку } \\
\text { в Україні та світі }\end{array}$ & $\begin{array}{l}\text { Усі можливі місця відпочинку } \\
\text { в Україні та світі }\end{array}$ \\
\hline $\begin{array}{l}\text { 4. Характер } \\
\text { відпочинку }\end{array}$ & $\begin{array}{l}\text { Туристично- } \\
\text { масовий } \\
\text { (екскурсійні тури, } \\
\text { тури вихідного } \\
\text { дня), лікувально- } \\
\text { оздоровчий }\end{array}$ & $\begin{array}{l}\text { Туристично-масовий } \\
\text { (екскурсійні тури, тури } \\
\text { вихідного дня, святкові тури, } \\
\text { шопінг, дитячий відпочинок, } \\
\text { гірськолижні тури, відпочинок } \\
\text { на морі), лікувально-оздоровчий, } \\
\text { культурно-просвітній }\end{array}$ & $\begin{array}{l}\text { Дитячий, молодіжний, сімейний, } \\
\text { для осіб похилого віку, для } \\
\text { інвалідів, культурно- просвітній, } \\
\text { лікувально-оздоровчий, спортивний, } \\
\text { релігійний, екологічний (зелений), } \\
\text { сільський, підводний, гірський, } \\
\text { пригодницький, мисливський, } \\
\text { автомобільний, самодіяльний тощо; } \\
\text { - Екскурсійні тури, спа-тури, } \\
\text { шопінг, екстрім-тури, тури вихідного } \\
\text { дня, святкові тури, гірськолижні } \\
\text { тури, відпочинок на морі, круїзи } \\
\text { та ін. }\end{array}$ \\
\hline $\begin{array}{l}\text { 5. Тривалість } \\
\text { відпочинку }\end{array}$ & $\begin{array}{l}\text { Сезонний } \\
\text { характер }\end{array}$ & $\begin{array}{l}\text { Цілий рік, із заздалегідь } \\
\text { визначеними термінами }\end{array}$ & $\begin{array}{l}\text { Цілий рік (в будь-яке місце в будь- } \\
\text { який час, тривалість споживач } \\
\text { обирає сам) }\end{array}$ \\
\hline 6. Харчування & Трьохразове & Чотирьохразове & $\begin{array}{l}\text { Повне, цілодобове, високої якості } \\
\text { (екологічно чисте), на вибір клієнта }\end{array}$ \\
\hline $\begin{array}{l}\text { 7. Комплексність } \\
\text { послуг }\end{array}$ & $\begin{array}{l}\text { Розміщення, } \\
\text { харчування, } \\
\text { екскурсійна } \\
\text { програма }\end{array}$ & $\begin{array}{l}\text { Проїзд, трансфер, розміщення, } \\
\text { харчування, екскурсійна } \\
\text { програма }\end{array}$ & $\begin{array}{l}\text { Проїзд, трансфер, розміщення, } \\
\text { харчування, страхування, } \\
\text { врахування пропозицій кліента, } \\
\text { екскурсійна програма, оформлення } \\
\text { виїзних документів }\end{array}$ \\
\hline
\end{tabular}

Джерело: складено авторол за данили підприєлства

За результатами аналізу, можна зробити висновки, що найбільш впливовими фракторами макросередовища $є$ візові режими між країнами, зменшення купівельної спроможності, підвищення цін на транспортні послуги та відсутність сприятливих економічних умов, які дозволяють громадянам забезпечувати високий рівень соціального споживання.

Для з'ясування конкурентного статусу туристичного підприемства ПП «КАЙФ» потрібно оцінити в балах його позицію серед конкурентів - тобто підприемств, які надають аналогічні послуги в даному сегменті ринку на даній території (табл. 6).

Як можна бачити із проведеного дослідження, найбільш конкурентні позиції має туристичне підприемство «TUI» та «TezTour».

Отже, можна зробити висновок, що головними заходами сприяючими розвитку діяльності туристичного підприемства ПП «КАЙФ» в умовах конкуренції можна вважати: покращення іміджу за рахунок поліпшення якості туристичного продукту (послуг) та додаткових носіїв реклами; підвищення обсягів виробництва (продажів) за допомогою введення системи стимулювання власних працівників відділів продажів та маркетингу; розширення збутової мережі за допомогою пошуку нових партнерів і початок використання технологічних інновацій; розробка інноваційних програм (турів); модифікація цінової політики за допомогою встановлення знижок.

Висновки і пропозиції. У даний час конкуренція на ринку туристичних послуг постійно зростае та загострюеться і саме через це туристичне підприемство ПП «КАЙФ» має реалізувати безперервний моніторинг місця на ринку, визначати та аналізувати свої переваги та слабкі сторони, намагатися своєчасно (а саме швидше за конкурентів) пристосовуватись до змін ринкових ситуацій, що вимагае розробки об'єктивної оцінки його конкурентних позищій. Задля того, щоб займати стійкі лідируючі позиції, підприемству необхідно мати конкурентні переваги.

У поточній ситуації туристичному підприемству ПП «КАЙФ» має сенс дотримуватися наступної конкурентної стратегії: використовувати на максимум свої «можливості» для мінімізації своїх «слабких сторін».

Одними з основних конкурентних заходів при даній стратегії можуть бути:

- постійно поновлювати свій персонал висококваліфікованими працівниками, задля того, щоб відбувалося стимулювання розвитку підприемства ПП «Кайф», адже нові працівники мають «свіжі» ідеї та міркування щодо поточної ситуації; 
РEST-аналіз туристичного підприемства ПП «КАЙФ»

\begin{tabular}{|c|c|c|c|c|}
\hline $\begin{array}{c}\text { Група } \\
\text { факторів }\end{array}$ & Можливість & $\begin{array}{l}\text { Ступінь } \\
\text { впливу }\end{array}$ & Загроза & $\begin{array}{l}\text { Ступінь } \\
\text { впливу }\end{array}$ \\
\hline 1 & 2 & 3 & 4 & 5 \\
\hline \multirow{3}{*}{$\begin{array}{l}\text { Політичні і } \\
\text { правові }\end{array}$} & 1. Стабільна політична ситуація в країні & 2 & $\begin{array}{l}\text { 1. Недосконалість державної } \\
\text { політики у сфері інвестування }\end{array}$ & 2 \\
\hline & $\begin{array}{l}\text { 2. Державне регулювання туристичної } \\
\text { діяльності }\end{array}$ & 4 & 2. Візові режими між країнами & 4 \\
\hline & $\begin{array}{l}\text { 3. Створення конкурентоспроможного } \\
\text { туристичного комплексу, що задовольняе } \\
\text { потреби вітчизняних і зарубіжних } \\
\text { туристів у різноманітних послугах, } \\
\text { розвиток суміжних галузей економіки } \\
\end{array}$ & 3 & $\begin{array}{l}\text { 3. Неефективна практика } \\
\text { виконання існуючого } \\
\text { законодавства }\end{array}$ & 2 \\
\hline \multirow{4}{*}{ Економічні } & 1. Зростання купівельної спроможності & 3 & $\begin{array}{l}\text { 1. Зменшення купівельної } \\
\text { спроможності }\end{array}$ & 4 \\
\hline & 2. Істотне уповільнення темпів інфляції & 2 & $\begin{array}{l}\text { 2. Підвищення цін на } \\
\text { транспортні послуги }\end{array}$ & 4 \\
\hline & \multirow{2}{*}{ 3. Продовження економічного зростання } & \multirow{2}{*}{3} & 3. Недосконалість оподаткування & 3 \\
\hline & & & 4. Несприятливий діловий клімат & 3 \\
\hline \multirow{4}{*}{ Соціальні } & $\begin{array}{l}\text { 1. Зростання реальних грошових доходів } \\
\text { населення }\end{array}$ & 4 & $\begin{array}{l}\text { 1. Зростання сумарної } \\
\text { заборгованості з заробітної } \\
\text { плати }\end{array}$ & 4 \\
\hline & $\begin{array}{l}\text { 2. Зростання схильності населення до } \\
\text { організованих заощаджень }\end{array}$ & 4 & $\begin{array}{l}\text { 2. Соціальна незахищеність } \\
\text { населення }\end{array}$ & 2 \\
\hline & $\begin{array}{l}\text { 3. Зростання кількості кваліфікованих } \\
\text { фахівців внаслідок підвищеної уваги } \\
\text { молоді до освіти }\end{array}$ & 2 & $\begin{array}{l}\text { 3. Відсутність сприятливих } \\
\text { економічних умов, які } \\
\text { дозволяють громадянам } \\
\text { забезпечувати високий рівень } \\
\text { соціального споживання } \\
\end{array}$ & 4 \\
\hline & $\begin{array}{l}\text { 4. Вивчення і застосування закордонного } \\
\text { досвіду, використання ефективних } \\
\text { методів управління }\end{array}$ & 2 & 4. Високий рівень смертності & 2 \\
\hline Технічні & $\begin{array}{l}\text { 1. Впровадження програм інформатизації } \\
\text { та розвитку економічної діяльності на } \\
\text { основі інтернет-технологій та інших } \\
\text { сучасних інформаційних технологій, } \\
\text { системи електронної комерції }\end{array}$ & 4 & $\begin{array}{l}\text { 1. Можливість використання } \\
\text { конкурентами сучасних } \\
\text { технологій, які дозволяють } \\
\text { зайняти більш вигідне становище } \\
\text { за асортиментом туристських } \\
\text { послуг та рівнем витрат } \\
\end{array}$ & 3 \\
\hline
\end{tabular}

Джерело: складено автором за даними підприемства

Бальна оцінка позицій туристичного підприемства ПП «КАЙФ» серед головних конкурентів

\begin{tabular}{|l|c|c|c|}
\hline \multicolumn{1}{|c|}{ Показники } & ПП «Кайф» & «TezTour» & «TUI» \\
\hline Місце розташування & 10 & 8 & 7 \\
\hline Популярність серед населення & 8 & 9 & 9 \\
\hline Рівень професіоналізму персоналу & 6 & 7 & 9 \\
\hline Якість основних послуг & 6 & 8 & 8 \\
\hline Асортимент додаткових послуг & 5 & 6 & 9 \\
\hline Якість рекламних засобів & 7 & 9 & 6 \\
\hline Цінова політика & 8 & 7 & 8 \\
\hline Середній бал & 7,14 & 7,71 & \\
\hline
\end{tabular}

Джерело: складено автором за даними підприемства

- слідкувати за появою сучасних інформаційних технологій та впроваджувати їх, а також впроваджувати інтернет-технології, що дасть змогу покращити організащію маркетингу на підприемстві. Використовуючи рекламу в інтернеті підприемство стане відомішою і більша кількість споживачів будуть поінформовані про підприемство та його;

- слід надати посередникам вигідні для фірми форми оплати та умови отримання послуг. Все це дасть змогу розробити більш ефективну стратегію розвитку підприемства, а саме товарну (продуктову) стратегію;

- високий ступінь прихильності покупців до послуг форми, зростання реальних грошових доходів населення та правильна організація стратегії діяльності туристичної фірми, призводить до збільшення обсягів реалізації послуг;

- покращення діяльності фірми та ії позищій на туристичному ринку послуг регіону, стимулюватиме стабільність у кадровій політиці підприемства. 


\section{Список літератури:}

1. Ансоффр I. Стратегічне управління. URL: https://gtmarket.ru/library/basis/4155

2. Котлер Ф., Армстронг Г. Основы маркетинга. Профессиональное издание. URL: https://altairbook.com/ books/982833862-osnovy-marketinga-professionalnoe-izdanie.html

3. Маркетинг : учебник для вузов / Г.Л. Багиев, В.М. Тарасевич, Х. Анн ; под общ. ред. Г.Л. Багиева. 2-е изд., перераб. и доп. Москва : ЗАО «Изд-во “Экономика”», 2001. 718 с.

4. Офіційний веб-сайт Tohology tourism and hospitality. URL: https://www.tohology.com/hospitality/industry/ unwto-statistika-mezhdunarodnyh-poezdok/

5. Офіційний веб-сайт Державної служби статистики України. URL: http://www.ukrstat.gov.ua/

6. Портер M. Конкурентная стратегия: Методика анализа отраслей конкурентов. URL: https://www.livelib.ru/ book/1005526144-konkurentnaya-strategiya-metodika-analiza-otraslej-konkurentov-majkl-porter

\section{References:}

1. Ansoff I. Strategic management. URL: https://gtmarket.ru/library/basis/4155

2. Kotler F., Armstrong G. Fundamentals of Marketing. Professional edition. URL: https://altairbook.com/ books/982833862-osnovy-marketinga-professionalnoe-izdanie.html

3. Marketing: a textbook for universities (2001) / G.L. Bagyev, V.M. Tarasevich, H. Ann; under common ed. G.L. Bagyeva. 2nd ed., reworked. and ext. Moscow: CJSC «Publishing House "Economy"», 718 p.

4. Official website Tohology tourism and hospitality. URL: https://www.tohology.com/hospitality/industry/unwtostatistika-mezhdunarodnyh-poezdok/

5. Official website of the State Statistics Service of Ukraine. URL: http://www.ukrstat.gov.ua/

6. Porter M. Competitive strategy: Methods of analysis of competitors' industries. URL: https://www.livelib.ru/ book/1005526144-konkurentnaya-strategiya-metodika-analiza-otraslej-konkurentov-majkl-porter 